\title{
Petrology of the April 2015 eruption of Calbuco volcano, southern Chile
}

\author{
OLIVIER NAMUR ${ }^{1}$ AND JACQUELINE VANDER \\ AUWERA $^{2}$
}

${ }^{1}$ Katholieke Universiteit, Leuven

${ }^{2}$ University of Liege

Presenting Author: olivier.namur@kuleuven.be

Understanding the origin of intermediate magmas that commonly erupt from subduction zone volcanoes is important to better constraining the mechanisms of continental crust formation. We performed a detailed mineralogical and petrological study of the eruptive products from April 2015 eruption of Calbuco volcano, Chile, a three-phase sub-Plinian eruption that produced pyroclastic deposits of andesitic composition. The eruptive products comprise a glass phase and a high but variable proportion of minerals dominated by plagioclase, clinopyroxene, and orthopyroxene, with minor olivine, amphibole, and magnetite. Plagioclase is very strongly zoned with highly anorthitic cores surrounded by more albitic rims, and no intermediate compositions between them. Based on thermodynamic calculations and published experimental data, we estimate that the anorthitic cores crystallized from a basaltic andesite melt containing 3.5-4.5 wt. $\% \mathrm{H}_{2} \mathrm{O}$. The bulk-rock major and trace element variability at Calbuco is best explained by the accumulation of minerals ( $72 \%$ plagioclase, $28 \%$ pyroxene) in a dacitic melt. These minerals most likely formed in the crystal mush zone of the magma chamber, at 200-300 MPa $(8-11 \mathrm{~km}$ depth) according to pyroxene and amphibole compositions. A few weeks to months before the eruption, the crystal mush was disaggregated, perhaps due to magmatic underplating, and a crystal-bearing dacitic melt migrated into a sub-surface storage region where the albitic plagioclase rims crystallized. The eruption was probably internally triggered by over-pressurization in the shallow magma chamber. 